
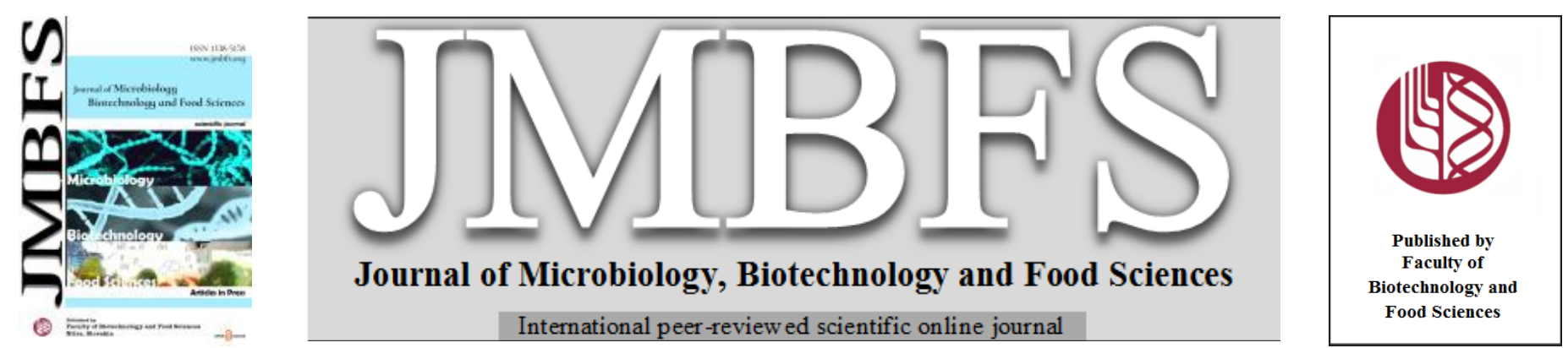

\title{
THE PHYSICAL AND CHEMICAL PROPERTIES OF THE JUJUBE FRUITS AT DIFFERENT MATURATION STAGES
}

\author{
Fadime Begüm TEPE* ${ }^{* 1}$, Raci EKINNCIII, Ayten EKINCI'²
}

Address(es):

${ }^{1}$ Deparment of Food Engineering, Faculty of Engineering, Pamukkale University, Denizli, Turkey.

${ }^{2}$ Department of Chemistry and Chemical Processing Technologies, Vocational School of Gemerek, Sivas Cumhuriyet University, Sivas, Turkey.

*Corresponding author: begumotag@gmail.com

https://doi.org/10.55251/jmbfs.4370

\section{ARTICLE INFO}

Received 20. 2. 2021

Revised 15. 8. 2021

Accepted 2. 9. 2021

Published 1. 2. 2022

Regular article OPEN $\partial_{\text {ACCESS }}$

\begin{abstract}
The effects of maturation stages on some physical and chemical properties of the jujube fruits were investigated. The maturation stages of the jujube fruits were described as green, yellow, half-red and red maturation. The physical properties and chemical composition of the jujube fruit significantly changed depending on the maturation stage. The size and weight of the jujube fruits increased, and the peel color changed from green to red with the maturation. The content of water-soluble vitamins, trans-resveratrol, total phenolic content and antioxidant capacity of the jujube fruits decreased during the maturation. The trans-resveratrol content of the jujube fruits was investigated for the first time and no trans-resveratrol content could be detected at red maturation stage. The major organic acid and sugar at the red maturation stage were found to be malic acid and sucrose, respectively. The phenolic composition also changed, but these changes showed unstable trend during the maturation. The major phenolic compound was catechin at the green maturation stage, whereas chlorogenic acid dominated at the red maturation stage. The jujube fruit is rich in minerals especially potassium and no changes in the mineral contents except for copper was observed between green and red maturation stages.
\end{abstract}

Keywords: chemical composition, jujube, HPLC, maturation stage

\section{INTRODUCTION}

Jujube (Zizyphus jujube Mill), belonging to Rhamnaceae family, has been grown in China for thousands of years (Guo et al., 2010). Additionally, the jujube has been naturally grown in Asia, Europe, India, Iraq, Java, Malacca, Nigeria, Spain and Turkey (Akbolat $\boldsymbol{e t}$ al., 2008). In different cultures various names have been used for the jujube such as chinese date, dara, hong zao, nan tsao, liane crocs chien, azufaifo, petite pomme, pomme malcadi, ta tsao, ünnap, annap and hünnap (Akbolat et al., 2008; Hernandez et al., 2016). The jujube fruit is a drupe which has a round-elliptic shape and apple-like taste (Wojdylo et al., 2016a) Consumption types of the jujube fruit can be sorted mainly fresh and dried as well tea, alcoholic beverage, pickle, jam or candy (Zozio et al., 2014; Wojdylo et al., 2016b).

The jujube, which has been used in traditional Chinese medicine for years due to its nutritional and bioactive properties, is recommended in the treatment of tumors and cardiovascular diseases associated with the formation of radical species resulting from oxidative stress (Zhang et al., 2010). This effect of the jujube can be explained with the antioxidant compounds. Free radical scavenging ability, chain propagation, suppressing the radical formation can be classified as the forms of antioxidant activity. As a result of this activity, human body could be preserved from the oxidative stress. Antioxidants naturally found in fruits and vegetables, such as ascorbic acid and phenolic compounds (Tepe et al., 2021). Thanks to rich content of the flavonoid, polyphenol, polysaccharide, protein, amino acid, fatty acids, nucleotide, triterpene, saponin, alkaloid, minerals, vitamins and other bioactive substances, the jujube acts as an antioxidant, antimicrobial, antitumor, hepatoprotective, sedative, blood-building and immune booster (Liu et al., 2017) The jujube fruit is rich in $\mathrm{C}$ and $\mathrm{B}$ complex vitamins and calcium $(\mathrm{Ca})$, iron $(\mathrm{Fe})$ and potassium $(\mathrm{K})$ minerals (Pareek, 2013; Wojdylo et al., 2016b).

The peel color of jujube fruit changes from green to red during maturation. Maturation stages of jujube are generally defined with these colors and the maturation stages of jujube can be divided four: green maturity, yellow or white maturity, half-red maturity and red maturity (Wang et al., 2016). Fruit maturation is a complex process and is an important criterion in terms of fruit quality and desired taste (Patel and Rao, 2009). Wang et al. (2016) stated that the jujube fruits at green maturation stage is not appropriate for consumption or processing. With the maturation, a series of biochemical reactions occur, such as hydrolysis of pectins, metabolism of sugars and acids, production of carotenoids, and exchange of phenolic compounds (Brummell, 2006; Prasanna et al., 2007). It is very important to define physical and chemical properties of a fruit during maturation in terms of commercial value of that fruit. To the best of our knowledge, no detailed data on the physical and chemical properties of the jujube fruits cultivated in Turkey was found in the literature. It was thought that this is a gap for the jujube fruits. In this study changes in physical and chemical properties of jujube fruits, which are cultivated in Turkey, during four maturation stages were investigated.

\section{MATERIAL AND METHODS}

\section{Materials}

The jujube fruits were obtained from a local producer in Denizli, a province of Turkey. Before analysis, jujube fruits were washed for removing foreign materials. The maturation stages of the jujube fruits were determined according to peel color. In this study, maturation stages of the jujube fruits were described as green maturation stage (GM), yellow maturation stage (YM), half-red maturation stage (HRM) and red maturation stage (RM). All chemicals were HPLC grade and were purchased from Sigma-Aldrich (Steinheim, Germany).

\section{Physical analysis}

Dry matter content and total soluble solid content of the jujube fruits at different maturation stage were performed according to Cemeroğlu (2013). For total soluble solid analysis, a digital refractometer (Milwaukee, MA871, Europe) was used, and results were given as Brix $\left(^{\circ}\right)$.

Size measurement of the jujube fruits at different maturation stages was carried out with a digital caliper (Mitotoyo, Japan) with the $0.01 \mathrm{~mm}$ accuracy. The size measurement of the jujube fruits at different maturation stages was performed separately, and 100 pieces of the jujube fruits at each maturation stage were randomly selected and averaged (Akbolat $\boldsymbol{e t}$ al., 2008). Weight of the 200 pieces of the jujube fruits at different maturation stages was measured with a digital weight measure (LF 225 D Vibration, Turkey) with $0.01 \mathrm{~g}$ precision.

Reflectance color value of the jujube fruit peel was measured by using Hunter Lab Color Miniscan XE (45/0-L, USA). The samples were placed on white background and the measurement was performed by covering a transparent glass. 


\section{Chemical analysis}

\section{pH and titratable acidity}

$50 \mathrm{~g}$ of pitted jujube fruits was homogenized with distilled water $(1: 1, \mathrm{w} / \mathrm{v})$. After $30 \mathrm{~min}$ at room temperature, the mixture was filtrated, and the $\mathrm{pH}$ value of samples was measured by using a digital $\mathrm{pH}$-meter (PL-700PV, Gondo-Tayvan). Besides, titratable acidity of the filtrate was measured with method suggested by Cemeroğlu (2013). Titratable acidity of the jujube fruits at different maturation stage was expressed as malic acid.

\section{Ash analysis}

Ash content of the jujube fruits was calculated with a method suggested by Cemeroğlu (2013). $5 \mathrm{~g}$ of the jujube fruit was weighted in crucible, which is constant weight and burned at $550^{\circ} \mathrm{C}$ in an ash oven (Selecta, FM 515, Italy) until existing ash color.

\section{Preparation of water extract of the jujube fruits}

An extraction method, recommended by Dönmez (2015), was used for the wate extract of the jujube fruits. After homogenization of $5 \mathrm{~g}$ of the jujube fruit with distilled water $(1: 9, \mathrm{w}: \mathrm{v})$, the homogenate was centrifuged at $4500 \mathrm{rpm}$ for $10 \mathrm{~min}$ (Nüve NF 800R). The supernatant obtained from centrifugation was filtrated by using a $0.45 \mu \mathrm{m}$ filter before injected into the HPLC device.

\section{Preparation of methanolic extract of the jujube fruits}

An extraction method, suggested by Choi et al. (2012), was used for methanolic extraction of jujube fruits. Samples were homogenized with methanol $(90 \%$ methanol:distilled water) in a rate of 1:9 (sample:methanol). The homogenate was filtered and then the filtrate was centrifuged at $4500 \mathrm{rpm}$ for $10 \mathrm{~min}$. The supernatant obtained from centrifugation was filtrated by using a $0.45 \mu \mathrm{m}$ filter to be injected into the HPLC.

\section{Analysis of water-soluble vitamins}

Water extract of the jujube fruits was used for analysis of the water-soluble vitamins. Analysis were performed according to Ekinci and Kadakal (2005). A micro syringe (Hamilton) was used for injection of $20 \mu \mathrm{L}$ of last filtrate into the HPLC column. Mobil phase consisted of $0.1 \mathrm{M}$ HPLC grade $\mathrm{KH}_{2} \mathrm{PO}_{4}$ at $\mathrm{pH} 7$. A HPLC device (SHIMADZU, Japan), column oven at $25{ }^{\circ} \mathrm{C}$ (SHIMADZU CTO20A), column ACE C18 (7.8x300 mm), pump (SHIMADZU LC-20AD), degasser (SHIMADZU DGU-20A3), photo diode array (PDA) detector (SPD-M20A) at 254 $\mathrm{nm}, 261 \mathrm{~nm}, 324 \mathrm{~nm}, 234 \mathrm{~nm}$ for ascorbic acid, niacin, pyridoxine and thiamin respectively were used for analysis. The mobile phase was isocratic with $0.8 \mathrm{~mL}$ $\mathrm{min}^{-1}$ flow rate. For riboflavin analysis, column is Macherey-Nagel NH2 (4.6x250 $\mathrm{mm}$ ), column oven at $40{ }^{\circ} \mathrm{C}$ and wavelength is $266 \mathrm{~nm}$. The same mobile phase was isocratic with $0.8 \mathrm{ml} \mathrm{min} \mathrm{m}^{-1}$ flow rate. Each analysis was performed in triplicate.

\section{Analysis of organic acids}

Composition of organic acids (malic, tartaric, citric and succinic acid) in the jujube fruits was determined with a method suggested by Soyer et al. (2003). Waterextracts of the jujube fruits were used for the analysis of organic acids. $20 \mu \mathrm{L}$ of the last filtrate was injected into the HPLC device by using a micro syringe. A HPLC device (SHIMADZU, Japan), column oven at $25^{\circ} \mathrm{C}$ (SHIMADZU CTO20A), column Coregel 87H3 $(7.8 \times 300 \mathrm{~mm})$, pump (SHIMADZU LC-20AD), degasser (SHIMADZU DGU-20A3), photo diode array (PDA) detector (SPDM20A) at $214 \mathrm{~nm}$ were used for analysis. The mobile phase consisting of HPLC grade $0.01 \mathrm{~N} \mathrm{H}_{2} \mathrm{SO}_{4}$ was isocratic with $1 \mathrm{~mL} \mathrm{~min}^{-1}$ flow rate. Each analysis was performed in triplicate.

\section{Analysis of sugars}

Sugar composition (glucose, fructose and sucrose) of the jujube fruits was determined with the method suggested by Karkacier et al. (2003). Water-extracts of the jujube fruits were used for the analysis of sugars. $20 \mu \mathrm{L}$ of the last filtrate was injected into the HPLC device with using a micro syringe. A HPLC device (SHIMADZU, Japan), column oven at $25^{\circ} \mathrm{C}$ (SHIMADZU CTO-20A), Bio Rad Aminex HPX-87 ion exclusion column (300x7.8 mm), pump (SHIMADZU LC 20AD), degasser (SHIMADZU DGU-20A3), photo diode array (PDA) detector (SPD-M20A) at $190 \mathrm{~nm}$ were used for analysis. The mobile phase consisting of acetonitrile:distilled water $(75: 25, \mathrm{v}: \mathrm{v})$ was isocratic with $1.4 \mathrm{~mL} \mathrm{~min}^{-1}$ flow rate Each analysis was performed in triplicate.

\section{Phenolic composition of the jujube fruits}

Definition of phenolic composition and calculation of the phenolic content analysis were carried out according to Bansal et al. (2015) with a slight modification. Methanolic extracts of the jujube fruits were used for the analysis of the phenolic compounds. $20 \mu \mathrm{L}$ of the last filtrate was injected into the HPLC device with using a micro syringe. A HPLC device (SHIMADZU, Japan), column oven at $25^{\circ} \mathrm{C}$ (SHIMADZU CTO-20A), Thermo Scientific BDS Hypersil C18 (100x4,6 mm, 3 $\mu \mathrm{m})$ column, pump (SHIMADZU LC-20AD), degasser (SHIMADZU DGU20A3), photo diode array (PDA) detector (SPD-M20A) was used for analysis. Peaks were monitored at $280 \mathrm{~nm}$ for the chlorogenic acid, catechin, epicatechin, $\mathrm{p}$ coumaric and cafeic acid; at $360 \mathrm{~nm}$ for rutin; at $255 \mathrm{~nm}$ for hyperoside; at $370 \mathrm{~nm}$ for quercetin and isoquercetin; at $271 \mathrm{~nm}$ for gallic acid and at $254 \mathrm{~nm}$ for ellagic acid. Mobile phase consisted of $0.1 \%$ orto-phosphoric acid (A) and $100 \%$ acetonitrile (B) and was gradient with the $0.5 \mathrm{~mL} \mathrm{~min}^{-1}$ flow rate. The gradient eluation was $95 \% \mathrm{~A}$ at $0-5 \mathrm{~min} ; 50 \% \mathrm{~A}$ at $5-25 \mathrm{~min}$ and finally $95 \% \mathrm{~A}$ at $25-30$ min. Each analysis was performed in triplicate.

\section{Analysis of trans-resveratrol}

Analysis of trans-resveratrol was performed with the method suggested by Singh and Pai (2014). Methanolic extracts of the jujube fruits were used for the analysis of trans-resveratrol. $20 \mu \mathrm{L}$ of the last filtrate was injected into the HPLC device with using a micro syringe. A HPLC device (SHIMADZU, Japan), column oven at $30{ }^{\circ} \mathrm{C}$ (SHIMADZU CTO-20A), Thermo Scientific BDS Hypersil C18 (100x4.6 $\mathrm{mm}, 3 \mu \mathrm{m}$ ) column, pump (SHIMADZU LC-20AD), degasser (SHIMADZU DGU-20A3), photo diode array (PDA) detector (SPD-M20A) at $306 \mathrm{~nm}$ were used for analysis. The mobile phase consisting of methanol:0.01 M KH2PO4: acetonitrile $(63: 30: 7)$ was isocratic with $0.8 \mathrm{~mL} \mathrm{~min}^{-1}$ flow rate. Each analysis was performed in triplicate.

\section{Analysis of total phenolic content and antioxidant capacity}

Total phenolic content (TPC) analysis was performed according to Singleton and Rossi (1965) with a slight modification. $1500 \mu \mathrm{L}$ of Folin-ciocalteu solution (10\% $\mathrm{v} / \mathrm{v}$ ) were added into $300 \mu \mathrm{L}$ of the methanolic extract and the mixture was kept in a dark place for $3 \mathrm{~min}$. After adding $1200 \mu \mathrm{L}$ of aqueous $7.5 \% \mathrm{Na}_{2} \mathrm{CO}_{3}$ into the mixture, the mixture was incubated at room temperature in a dark place for 2 hours. At the end of the incubation, the absorbance of samples was measured at $760 \mathrm{~nm}$ by using a spectrophotometer (T80, PG Ins. UK.). Each analysis was carried out in triplicate and TPC was expressed as $\mathrm{mg} 100 \mathrm{~g}^{-1}$ gallic acid equivalent (GAE) in dry weight (DW).

The antioxidant capacity (AC) analysis was carried out by using a method suggested by Thaipong et al. (2006) with slight modification. $150 \mu \mathrm{L}$ of the methanolic extracts and $2850 \mu \mathrm{L}$ of DPPH methanolic solution, whose absorbance is 1.1 at $515 \mathrm{~nm}$, were mixed. After 60 min-incubation at the room temperature in a dark place, the absorbance of samples was measured at $515 \mathrm{~nm}$. Each sample was analyzed in triplicate and $\mathrm{AC}$ were expressed as mmol trolox equivalent (mmol TE) $g^{-1}$ in DW.

\section{Analysis of mineral composition}

Mineral composition and content of each mineral in the jujube fruits at different maturation stage were determined by using the ICP-MS (AGILENT/7800) with the NKML 186 (2007) method.

\section{Statistical analysis}

All of data was presented as the mean value \pm standard deviation. All statistica analysis was carried out by using SPSS software (ver. 22 SPSS Inc., Chicago, IL, USA). One-way analysis of variance (ANOVA) and then Duncan post-hoc test was used for comparing the means at the significance level $\mathrm{p}<0.05$.

\section{RESULTS AND DISCUSSION}

\section{Physical properties of the jujube fruit at different maturation stage}

The weight and size of the jujube fruit have an important role in evaluating fruit quality and affect consumer appreciation. The size, weight of 200 fruits, total dry matter and total soluble solid values of the jujube fruit in different maturation stages are given in Table 1. During the maturation, the size of the fruit changed between $10.2 \times 11.8 \mathrm{~mm}$ and $15.2 \times 18.1 \mathrm{~mm}(\mathrm{p}<0.05)$, and the fruit size increased with maturation. Similarly, Choi et al. (2012) stated that the sizes of jujube fruits in eight different maturation stages reached from $6.5 \times 10.3 \mathrm{~mm}$ to $31.5 \times 40.2 \mathrm{~mm}$ during maturation. With the maturation, the weight of 200 fruits increased from $730.22 \mathrm{~g}$ to $1450.14 \mathrm{~g}$. Fruit weight varies depending on the species, growing conditions and maturation stage of the fruit (Gao et al., 2011; Gao et al., 2012b) An increment in the weight of the jujube fruit with the maturation was reported by Choi et al. (2012). The content of dry matter and total soluble solid of jujube fruits 
increased with maturation. Likewise, Cosmulescu et al. (2018) reported that the dry matter content and total soluble solids of two different types of the jujube fruits at four different maturation stages increased with the maturation. Increment in total soluble solid can be explained with the hydrolyze of starch into basic sugars (Wang et al., 2013; Zheng et al., 2012)

Table 1 Physical characteristics, $\mathrm{pH}$, titratable acidity and ash content of the jujube fruits at different maturation stage

\begin{tabular}{|c|c|c|c|c|}
\hline & GM & $\mathbf{Y M}$ & HRM & $\mathbf{R M}$ \\
\hline $\begin{array}{l}\text { Size } \\
(\mathrm{mm})\end{array}$ & $\begin{array}{l}\text { Width: } 10.2 \pm 0.02^{\mathrm{a}} \\
\text { Height: } 11.8 \pm 0.01^{\mathrm{a}}\end{array}$ & $\begin{array}{l}\text { Width: } 11.9 \pm 0.01^{\mathrm{b}} \\
\text { Height: } 13.7 \pm 0.03^{\mathrm{b}}\end{array}$ & $\begin{array}{l}\text { Width: } 12.1 \pm 0.02^{\mathrm{b}} \\
\text { Height: } 14.2 \pm 0.01^{\mathrm{b}}\end{array}$ & $\begin{array}{l}\text { Width: } 15.2 \pm 0.01^{\mathrm{c}} \\
\text { Height: } 18.1 \pm 0.02^{\mathrm{c}}\end{array}$ \\
\hline $\begin{array}{l}\text { Weight of } 200 \text { fruits } \\
(\mathrm{g})\end{array}$ & $730.22 \pm 4.86^{\mathrm{a}}$ & $1130.91 \pm 12.38^{b}$ & $1220.75 \pm 11.56^{\mathrm{c}}$ & $1450.14 \pm 13.65^{\mathrm{d}}$ \\
\hline $\begin{array}{l}\text { Total dry matter } \\
(\%)\end{array}$ & $15.94 \pm 0.7^{\mathrm{a}}$ & $16.00 \pm 0.82^{\mathrm{a}}$ & $20.64 \pm 0.74^{b}$ & $34.59 \pm 0.68^{\mathrm{c}}$ \\
\hline Total soluble solid $\left(\right.$ Brix $^{\circ}$ ) & $9.66 \pm 0.02^{\mathrm{a}}$ & $10.33 \pm 0.04^{\mathrm{b}}$ & $16.7 \pm 0.02^{\mathrm{c}}$ & $25.4 \pm 0.05^{\mathrm{d}}$ \\
\hline $\mathrm{L}$ & $41.00 \pm 0.06^{\mathrm{a}}$ & $44.48 \pm 0.22^{\mathrm{b}}$ & $25.41 \pm 0.13^{c}$ & $21.92 \pm 0.01^{\mathrm{d}}$ \\
\hline $\mathrm{a}$ & $-2.55 \pm 0.05^{\mathrm{a}}$ & $2.24 \pm 0.11^{\mathrm{b}}$ & $10.93 \pm 0.06^{\mathrm{c}}$ & $15.95 \pm 0.12^{\mathrm{d}}$ \\
\hline $\mathrm{b}$ & $16.77 \pm 0.09^{\mathrm{a}}$ & $18.43 \pm 0.1^{\mathrm{b}}$ & $13.22 \pm 0.13^{c}$ & $9.91 \pm 0.12^{\mathrm{d}}$ \\
\hline$\overline{\mathrm{pH}}$ & $5.09 \pm 0.07^{\mathrm{a}}$ & $4.74 \pm 0.06^{\mathrm{b}}$ & $4.39 \pm 0.06^{\mathrm{c}}$ & $4.43 \pm 0.08^{c}$ \\
\hline Titratable acidity (\%) & $0.30 \pm 0.013^{\mathrm{a}}$ & $0.36 \pm 0.012^{\mathrm{b}}$ & $0.44 \pm 0.015^{\mathrm{c}}$ & $0.43 \pm 0.016^{\mathrm{c}}$ \\
\hline Ash content $(\%)$ & $1.29 \pm 0.01^{\mathrm{a}}$ & $1.33 \pm 0.01^{\mathrm{b}}$ & $1.36 \pm 0.01^{\mathrm{b}}$ & $1.41 \pm 0.02^{\mathrm{c}}$ \\
\hline
\end{tabular}

Different letters in the same row are significantly different $(\mathrm{p}<0.05)$

Color is one of the most important quality parameters that indicates the final product quality and affects consumer preference. The color of agricultural products such as fruits and vegetables are due to natural pigments, many of which change with maturation. Moradinezhad et al. (2016) emphasized that the color change in the jujube fruit was considered as the maturation index. The color values of the jujube fruits in different maturation stages are given in Table 1 . The $\mathrm{L}$ and $\mathrm{b}$ value increased at the YM stage, then decreased, while the a value increased with maturation. Similar to the results of this study, Xie et al. (2017) reported that the $\mathrm{L}$ value of jujube fruits decreases with maturation, the value of a increases, and the value of $\mathrm{b}$ increases first and then decreases as the maturation progresses.

\section{pH and titratable acidity}

The $\mathrm{pH}$ and titratable acidity values of the jujube fruits at different maturation stages are given in Table 1 . The $\mathrm{pH}$ value showed a significant decrease $(\mathrm{p}<0.05)$ in the first three stages of maturation. Moreover, there was no significant difference between HRM and RM stages. While the titratable acidity was $0.30 \%$ in the GM stage, increased with maturation and reached $0.43 \%$ in fully mature samples. Similarly, an increment in titratable acidity of the jujube fruits during the maturation was reported by Wang et al. (2013) and Moradinezhad et al. (2016) During the maturation, increment of titratable acidity corresponded to decreasing $\mathrm{pH}$ of the jujube fruits.

\section{Ash content}

The ash content of the jujube fruits at different maturation stages is given in Table 1. As seen from Table 1, the ash content of the jujube fruits significantly increased with maturation $(\mathrm{p}<0.05)$. The content of ash in the jujube fruit was $1.29 \%$ at GM stage; $1.33 \%$ at YM stage; $1.36 \%$ at HRM stage; $1.41 \%$ at RM stage. The high amount of ash indicates that the jujube fruit is rich in minerals.

\section{Water soluble vitamins}

Vitamin C, thiamine, pyridoxine, riboflavin and niacin contents of the jujube fruits at different maturation stages are given in Table 2 . The highest vitamin $\mathrm{C}$ content (967.67 $\mathrm{mg} \mathrm{kg}^{-1} \mathrm{DW}$ ) was found at the GM stage, and vitamin $\mathrm{C}$ content dramatically decreased with maturation $(\mathrm{p}<0.05)$. There was no significan difference between the samples at the HRM and RM stages ( $>>0.05)$. Similarly, Wu et al. (2012) stated that content of vitamin $C$ in the jujube fruits decreased during the maturation. On the contrary, an increment in the vitamin $\mathrm{C}$ content of the jujube fruits with the maturation was reported by Cosmulescu et al. (2018) and Moradinezhad et al. (2016).

Table 2 The water-soluble vitamins, organic acids and sugar composition of the jujube fruits at different maturation stages

\begin{tabular}{lcccc}
\hline & GM & YM & HRM & RM \\
\hline $\begin{array}{l}\text { Ascorbic acid } \\
\text { Vitamin C) }\end{array}$ & $967.67 \pm 19.72^{\mathrm{a}}$ & $886.04 \pm 16.13^{\mathrm{b}}$ & $819.67 \pm 16.80^{\mathrm{c}}$ & $789.05 \pm 9.63^{\mathrm{c}}$ \\
\hline $\begin{array}{l}\text { Thiamin } \\
\text { (B1) }\end{array}$ & $0.2722 \pm 0.0151^{\mathrm{a}}$ & $0.2652 \pm 0.0214^{\mathrm{a}}$ & $0.2821 \pm 0.0128^{\mathrm{a}}$ & $0.2733 \pm 0.0151^{\mathrm{a}}$ \\
\hline $\begin{array}{l}\text { Prydoxine } \\
\text { (B6) }\end{array}$ & $0.9632 \pm 0.0252^{\mathrm{a}}$ & $0.9629 \pm 0.0216^{\mathrm{a}}$ & $0.8116 \pm 0.0213^{\mathrm{b}}$ & $0.8033 \pm 0.0208^{\mathrm{b}}$ \\
\hline $\begin{array}{l}\text { Riboflavin } \\
\text { (B2) }\end{array}$ & $0.3321 \pm 0.0254^{\mathrm{a}}$ & $0.4634 \pm 0.0153^{\mathrm{b}}$ & $0.4226 \pm 0.0154^{\mathrm{c}}$ & $0.4100 \pm 0.0100^{\mathrm{c}}$ \\
\hline $\begin{array}{l}\text { Niacin } \\
\text { (B3) }\end{array}$ & $1.0723 \pm 0.0254^{\mathrm{a}}$ & $9.6338 \pm 0.1534^{\mathrm{b}}$ & $8.9723 \pm 0.1538^{\mathrm{c}}$ & $8.8333 \pm 0.1527^{\mathrm{c}}$ \\
\hline Tartaric acid & $99.64 \pm 0.81^{\mathrm{a}}$ & $155.91 \pm 1.53^{\mathrm{b}}$ & $40.3 \pm 1.43^{\mathrm{c}}$ & $30.65 \pm 0.93^{\mathrm{d}}$ \\
\hline Malic acid & $84.88 \pm 1.58^{\mathrm{a}}$ & $207.31 \pm 3.04^{\mathrm{b}}$ & $159.88 \pm 5.79^{\mathrm{c}}$ & $103.11 \pm 1.60^{\mathrm{d}}$ \\
\hline Citric acid & $34.92 \pm 2.07^{\mathrm{a}}$ & $183.96 \pm 4.54^{\mathrm{b}}$ & $139.76 \pm 2.55^{\mathrm{c}}$ & $73.20 \pm 1.41^{\mathrm{d}}$ \\
\hline Succinic acid & $1.74 \pm 0.06^{\mathrm{a}}$ & $19.43 \pm 1.44^{\mathrm{b}}$ & $16.67 \pm 1.14^{\mathrm{c}}$ & $12.55 \pm 0.91^{\mathrm{d}}$ \\
\hline Glucose & $19.48 \pm 0.18^{\mathrm{a}}$ & $14.70 \pm 0.19^{\mathrm{b}}$ & $13.44 \pm 0.14^{\mathrm{c}}$ & $9.35 \pm 0.25^{\mathrm{d}}$ \\
\hline Fructose & $23.93 \pm 0.22^{\mathrm{a}}$ & $19.25 \pm 0.36^{\mathrm{b}}$ & $14.45 \pm 0.33^{\mathrm{c}}$ & $11.83 \pm 0.16^{\mathrm{d}}$ \\
\hline Sucrose & $3.59 \pm 0.13^{\mathrm{a}}$ & $21.90 \pm 0.34^{\mathrm{b}}$ & $30.73 \pm 0.22^{\mathrm{c}}$ & $34.71 \pm 0.39^{\mathrm{d}}$ \\
\hline Diffrent & & &
\end{tabular}

Different letters in the same row are significantly different $(\mathrm{p}<0.05)$

The contents of organic acids and vitamins were given as $\mathrm{mg} \mathrm{kg}^{-1} \mathrm{DW}$ and the content of sugars was given as $\mathrm{g} \mathrm{kg}^{-1} \mathrm{DW}$

No significant difference was observed in the content of thiamine with the maturation $(\mathrm{p}>0.05)$. The content of thiamine at RM stage was determined as $0.2733 \mathrm{mg} \mathrm{kg}^{-1} \mathrm{DW}$. While there was no significant difference between GM and YM stage in terms of pyridoxine, the content of pyridoxine decreased significantly at the HRM stage $(\mathrm{p}<0.05)$. Pyridoxine content at RM stage was found as 0.8033 $\mathrm{mg} \mathrm{kg}{ }^{-1}$ DW. No significant difference between HRM and RM stages was observed. The content of riboflavin found as $0.3321 \mathrm{mg} \mathrm{kg}^{-1} \mathrm{DW}$ at the GM stage, then, increased at the YM stage and was determined as $0.4634 \mathrm{mg} \mathrm{kg}^{-1} \mathrm{DW}$. After 
the HRM stage, the content of riboflavin decreased to $0.4100 \mathrm{mg} \mathrm{kg}^{-1} \mathrm{DW}$ at the RM stage. The content of niacin, which was determined as $1.0723 \mathrm{mg} \mathrm{kg}^{-1} \mathrm{DW}$ at the GM stage, increased in the samples at the YM stage and reached $9.6338 \mathrm{mg} \mathrm{kg}$ ${ }^{1} \mathrm{DW}(\mathrm{p}<0.05)$ and decreased again after this maturation stage. To the best of our knowledge, there is no published data on the changes in B complex vitamins in the jujube fruit during the maturation. Similar to this study, the content of thiamine, riboflavin, niacin and pyridoxine found in the fully mature jujube fruit was found to be $0.018,0.036,0.820$ and $0.076 \mathrm{mg} 100 \mathrm{~g}^{-1}$, respectively by Yaşa (2016) Additionally, Pareek (2013) reported that the content of thiamin, riboflavin and niacin in the fully mature jujube fruits were $0.020-0.024,0.020-0.038$ and $0.700-$

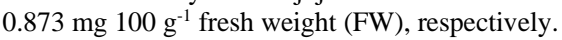

\section{Organic acids}

Organic acids and their contents in jujube fruits at four different maturation stages are given in Table 2. The major organic acid in the jujube fruit has been determined


significant increment was observed in the content of malic acid from the GM to YM stage. Following the YM stage, the content of malic acid showed dramatically decrement at the HRM and RM stages $(\mathrm{p}<0.05)$. Additionally, a significant increment in tartaric, citric and succinic acid contents was observed at the YM stage $(p<0.05)$, while these organic acids remarkably decreased at the HRM and RM stages. The amounts of tartaric, citric and succinic acid at RM stage

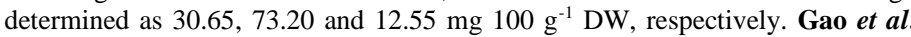
(2012a) stated that the amount of organic acids in jujube fruit varies greatly depending on the species and growing conditions. Similar to the results of this study, it was reported that the major organic acid was malic acid by Gao et al. (2012a). Likewise, Wu et al. (2012) indicated that the amounts of tartaric, malic, citric and succinic acid at six different maturation stages of the jujube fruits increased after the first maturation stage and decreased the next stages of maturation. Besides, it was reported that malic acid was the major organic acid in fully mature jujube fruits (Wu et al., 2012). In contrast to the results of this study, Hernandez et al. (2016) reported major organic acid in different jujube genotypes as succinic acid.

\section{Sugar composition}

Sugar composition of the jujube fruits at different maturation stages are given in Table 2. As seen from Table 2, remarkable changes were observed in the conten of glucose, fructose and sucrose based on the maturation stages. An increment was found in the content of sucrose, while the amount of glucose and fructose dramatically decreased $(\mathrm{p}<0.05)$. The glucose, fructose and sucrose contents at the RM stage were $9.35,11.83$ and $34.71 \mathrm{~g} \mathrm{~kg}^{-1} \mathrm{DW}$, respectively. It has been reported that the sugar composition and amount of the fruits differ according to the cultivar, genotype, growing conditions and maturation stage (Hernandez et al., 2016). Wu et al. (2012) indicated that the amount of glucose and fructose increased at the first four stages of maturation and decreased after the fourth maturation stage. Additionally, no sucrose content was detected at the first maturation stage, however, increment in sucrose content was reported at the later stages by $\mathbf{W u} e \boldsymbol{t}$ al. (2012). Similarly, Hernandez et al. (2016) reported that the major sugar in the fully mature jujube fruits was sucrose followed by fructose. Song et al. (2019) also stated that the highest amount of glucose $\left(228.6 \mathrm{mg} \mathrm{g}^{-1} \mathrm{DW}\right)$ and fructose $(277.8$ $\mathrm{mg} \mathrm{g}^{-1} \mathrm{DW}$ ) was observed in the jujube fruits at the GM stage. Moreover, the content of glucose and fructose decreased, however, sucrose content increased during the maturation. The decrement in the amount of glucose and fructose with maturation may be explained by the conversion of these sugars into polysaccharides or participation in some reactions (Bood and Zebetakis, 2002) On the contrary, Li et al. (2007) stated that the amount of sucrose was lower than the amount of fructose and glucose in 5 different fully mature jujube fruits. These results were explained with the hydrolysis of sucrose to glucose and fructose by $\mathbf{L}$ et al. (2007).

\section{Phenolic composition}

Phenolic composition of the jujube fruits at four maturation stages is given in Table 3. As seen from Table 3, significant changes were observed in the phenolic composition of jujube fruit depending on maturation. However, these changes followed unstable trend according to the maturation stages. During the maturation, phenolic compounds are exposed to a series of complex biosynthesis that will affect the amount and composition in fruits (Prasanna et al. 2007). In this study, epicatechin, catechin, caffeic, chlorogenic and ellagic acid decreased with maturation $(\mathrm{p}<0.05)$. In addition, $\mathrm{p}$-coumaric and gallic acid increased at the YM stage and decreased at the later stages of maturation. The amount of rutin and quercetin increased with maturation $(\mathrm{p}<0.05)$. While the major phenolic compound was catechin at the GM and YM stages, chlorogenic acid was the major phenolic compound at the HRM and RM stages. No isoquercetin and hyperoside were detected in any maturation stage. Wu et al. (2012) determined the major phenolic compound as cinnamic acid $\left(21.18 \mu \mathrm{g} 100 \mathrm{~g}^{-1} \mathrm{FW}\right)$ at the first stage of maturation, and chlorogenic acid ( $\left.38.73 \mu \mathrm{g} 100 \mathrm{~g}^{-1} \mathrm{FW}\right)$ in fully mature samples. Similar to the findings of this study, it was stated that the amount of catechin and epicatechin decreased with maturation (Hudec et al., 2007). This decrement in the amount of catechin and epicatechin was explained with the metabolism of these compounds or their synthesis into another phenolic compound by Hudec et al. (2007). In another study, it was reported that the amount of all flavonoids except for epicatechin decreased. However, the amount of epicatechin increased at the first six maturation stages, then rapidly decreased (Choi et al., 2012). In the same study, it was stated that rutin is the major flavanoid at the first stage of maturation. In addition to this, Wang et al. (2016) reported that the major phenolic compound in jujube fruit at three different maturation stages was rutin. Wang et al. (2016) also stated that caffeic acid decreased with maturation, while chlorogenic acid increased. Additionally, it was reported that no quercetin, gallic and rosmarinic acids were detected in any maturity stage by Wang $\boldsymbol{e t}$ al. (2016). Moreover, Xie $\boldsymbol{e}$ al. (2017) indicated that the amount of gallic acid, chlorogenic acid, caffeic acid and coumarin in the peels of the jujube fruits at three different maturation stages was higher than the amount of catechin, p-coumaric acid, ferulic acid, quercetin and epicatechin. Besides, the highest phenolic compounds content was observed at the second stage of maturation by Xie et al. (2017). These differences in the composition and amount of phenolic compounds may be explained by differences in genotype, growing conditions and maturation stage (Gull et al., 2012; Xie et al., 2017).

Table 3 Phenolic composition of the jujube fruits at different maturation stages $\left(\mathrm{mg} \mathrm{kg}^{-1} \mathrm{DW}\right)$

\begin{tabular}{lcccc}
\hline & GM & YM & HRM & RM \\
\hline Epicatechin & $189.32 \pm 16.53^{\mathrm{a}}$ & $87.42 \pm 9.36^{\mathrm{b}}$ & $32.18 \pm 6.14^{\mathrm{c}}$ & $19.45 \pm 3.56^{\mathrm{c}}$ \\
\hline Catechin & $264.58 \pm 28.67^{\mathrm{a}}$ & $154.75 \pm 12.69^{\mathrm{b}}$ & $107.18 \pm 8.32^{\mathrm{c}}$ & $91.74 \pm 6.12^{\mathrm{c}}$ \\
\hline p-Coumaric acid & $42.05 \pm 5.23^{\mathrm{a}}$ & $68.47 \pm 4.42^{\mathrm{b}}$ & $59.21 \pm 6.52^{\mathrm{bc}}$ & $46.84 \pm 4.63^{\mathrm{ac}}$ \\
\hline Caffeic acid & $87.79 \pm 7.12^{\mathrm{a}}$ & $38.91 \pm 5.23^{\mathrm{b}}$ & $26.46 \pm 6.87^{\mathrm{bc}}$ & $19.72 \pm 5.48^{\mathrm{c}}$ \\
\hline Rutin & $15.61 \pm 2.52^{\mathrm{a}}$ & $34.71 \pm 4.21^{\mathrm{b}}$ & $58.09 \pm 9.63^{\mathrm{c}}$ & $103.64 \pm 11.57^{\mathrm{d}}$ \\
\hline Chlorogenic acid & $215.92 \pm 17.42^{\mathrm{a}}$ & $132.96 \pm 10.61^{\mathrm{b}}$ & $157.72 \pm 12.88^{\mathrm{bc}}$ & $168.27 \pm 16.23^{\mathrm{c}}$ \\
\hline Ellagic acid & $154.08 \pm 14.66^{\mathrm{a}}$ & $48.36 \pm 5.17^{\mathrm{b}}$ & $37.17 \pm 6.58 \mathrm{~b}^{\mathrm{c}}$ & $24.09 \pm 3.98^{\mathrm{c}}$ \\
\hline Quercetin & $1.24 \pm 0.21^{\mathrm{a}}$ & $1.83 \pm 0.33^{\mathrm{a}}$ & $4.27 \pm 0.24^{\mathrm{b}}$ & $5.79 \pm 0.42^{\mathrm{c}}$ \\
\hline İsoquercetin & $\mathrm{ND}$ & $\mathrm{ND}$ & $\mathrm{ND}$ & $\mathrm{ND}$ \\
\hline Hyperoside & $\mathrm{ND}$ & $\mathrm{ND}$ & $\mathrm{ND}$ & $\mathrm{ND}$ \\
\hline Gallic acid & $12.58 \pm 2.54^{\mathrm{a}}$ & $46.67 \pm 5.28^{\mathrm{b}}$ & $28.93 \pm 3.26^{\mathrm{c}}$ & $29.18 \pm 2.78^{\mathrm{c}}$ \\
\hline
\end{tabular}

Different letters in the same row are significantly different $(\mathrm{p}<0.05)$

ND: Not detected

\section{Trans-resveratrol}

The contents of trans-resveratrol in the jujube fruits at different maturation stages are given in Table 4. The content of trans-resvaratrol in the jujube fruits statistically decreased with maturation and determined as $0.2166,0.1366$ and 0.07 $\mathrm{mg} \mathrm{kg}{ }^{-1} \mathrm{DW}$ at GM, YM and HRM stage, respectively. No trans-resveratrol content was observed at the RM stage. To the best of our knowledge, it was the first study in terms of investigation of trans-resveratrol in the jujube fruits. Giuffre (2013) stated that the content of trans-resveratrol in four different grape varieties decreased approximately $60 \%$ with maturation. Otağ (2015) reported that the content of trans-resveratrol in grapes dramatically decreased with maturation from $1.79-7.25 \mathrm{mg} \mathrm{L}^{-1}$ to $0.06-1.73 \mathrm{mg} \mathrm{L}^{-1}$.

\section{Total phenolic content and antioxidant capacity}

TPC and AC of the jujube fruits at different maturation stages are given in Table 5. TPC and AC significantly decreased with the maturation $(\mathrm{p}<0.05)$. TPC was determined as $9252.53 \mathrm{mg}$ GAE $100 \mathrm{~g}^{-1} \mathrm{DW}$ at the GM stage, and then decreased to $1911.40 \mathrm{mg}$ GAE $100 \mathrm{~g}^{-1} \mathrm{DW}$ at RM stage. It was reported that TPC of jujube fruit varies depending on the cultivars, growing conditions and maturation stage (Li et al., 2007; Zhao et al., 2014; Wojdylo et al., 2016b; Cosmulescu et al., 
2018). Similarly, Wang et al. (2016) and Cosmulescu et al. (2018) stated that a decrement in TPC with the maturation. Xue et al. (2009) indicated that the TPC in the peel of jujube fruit was higher than in pulp. This is explained with the fact that phenolic substances have an important role in protecting the fruit from ultraviolet radiation and damage such as pathogens. Therefore, phenolic compounds tend to concentrate in the peel (Toor and Savage 2005)

Table 4 The content of trans-resveratrol in the jujube fruits at different maturation stages (mg kg-1 DW)

\begin{tabular}{lc}
\hline Maturation stages & Trans-resveratrol content \\
\hline GM & $0.2166 \pm 0.1527^{\mathrm{a}}$ \\
\hline YM & $0.1366 \pm 0.0153^{\mathrm{b}}$ \\
\hline HRM & $0.0700 \pm 0.0100^{\mathrm{c}}$ \\
\hline RM & $\mathrm{ND}$ \\
\hline
\end{tabular}

Different letters in the same column are significantly different $(\mathrm{p}<0.05)$

ND: Not detected

Table 5 Total phenolic content and antioxidant capacity of the jujube fruits at different maturation stages

\begin{tabular}{lcc}
\hline $\begin{array}{l}\text { Maturation } \\
\text { stages }\end{array}$ & $\begin{array}{c}\text { Total phenolic content } \\
\left(\mathbf{m g ~ G A E ~} \mathbf{1 0 0} \mathbf{~ g}^{-1} \mathbf{D W}\right)\end{array}$ & $\begin{array}{c}\text { Antioxidant capacity } \\
\left(\mathbf{m m o l} \text { TE } \mathbf{~ g}^{-1} \mathbf{D W}\right)\end{array}$ \\
\hline GM & $9252.53 \pm 160.32^{\mathrm{a}}$ & $0.471 \pm 0.004^{\mathrm{a}}$ \\
\hline YM & $7541.35 \pm 193.71^{\mathrm{b}}$ & $0.470 \pm 0.006^{\mathrm{a}}$ \\
\hline HRM & $4030.62 \pm 79.84^{\mathrm{c}}$ & $0.381 \pm 0.005 \mathrm{~b}^{\mathrm{b}}$ \\
\hline RM & $1911.40 \pm 47.32^{\mathrm{d}}$ & $0.214 \pm 0.001^{\mathrm{c}}$ \\
\hline
\end{tabular}

Different letters in the same column are significantly different $(\mathrm{p}<0.05)$
AC of the jujube fruit ranged from 0.471 to $0.214 \mathrm{mmol} \mathrm{TE}^{-1} \mathrm{DW}$. It was reported that the highest antioxidant activity was observed in the jujube fruits, which are rich in flavonoid and phenolic compounds, and the antioxidant activity, tota phenolic and total flavonoid amount decreased with maturation by Gao et al (2012b). Cosmulescu et al. (2018) stated that the AC of the jujube fruits decreased with maturation. It was notified that the cultivar has great effect on the AC. Similar findings were reported by Wu et al. (2012), Choi et al. (2012), Wang et al. (2016) and Zozio et al. (2014). The decreasing of AC during maturation may be explained with the decrement of some bioactive compounds that have antioxidant activity such as phenolic compounds and ascorbic acid.

\section{Mineral composition}

Mineral composition of the jujube fruits at different maturation stages are given in Table 6. The jujube fruit was found as a fruit being rich in potassium and the highest potassium amount was found at RM stage (242.94 mg $\left.100 \mathrm{~g}^{-1} \mathrm{DW}\right)$ Following potassium, phosphorus $\left(19.39 \mathrm{mg} 100 \mathrm{~g} \mathrm{~g}^{-1} \mathrm{DW}\right)$ and calcium $(18.53 \mathrm{mg}$ $100 \mathrm{~g}^{-1} \mathrm{DW}$ ) were also defined as minerals found in high amounts in the jujube fruit. The amount of potassium and calcium in the fully mature jujube fruits were found to be $13.1 \mathrm{~g} \mathrm{~kg}^{-1}$ and $0.23-0.72 \mathrm{~g} \mathrm{~kg}^{-1}$ by Wang et al. (2014). Hernandez et al. (2016) determined iron (10.2-17.3 $\left.\mathrm{mg} \mathrm{kg}^{-1}\right)$, zinc (4.0-5.1 $\left.\mathrm{mg} \mathrm{kg}^{-1}\right)$, copper (0.5$\left.1.2 \mathrm{mg} \mathrm{kg}^{-1}\right)$ and manganese $\left(0.2-2.9 \mathrm{mg} \mathrm{kg}^{-1}\right)$ in the fully mature jujube fruits. $\mathbf{L i}$ et al. (2007) defined the major minerals in fully mature jujube fruits as potassium (79.2-458 mg $\left.100 \mathrm{~g}^{-1}\right)$, calcium (45-118 mg $\left.100 \mathrm{~g}^{-1}\right)$, phosphorus (59.3-110 mg 100

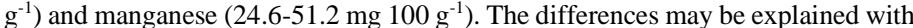
the genotype, maturation stage, agricultural practices, climate, altitude and soil ( $\mathbf{L i}$ et al., 2007; Hernandez et al., 2016).

\begin{tabular}{|c|c|c|c|c|}
\hline Minerals & GM & YM & HRM & RM \\
\hline Sodium & $4.28 \pm 0.07^{\mathrm{a}}$ & $4.67 \pm 0.11^{\mathrm{b}}$ & $3.98 \pm 0.12^{\mathrm{a}}$ & $3.71 \pm 0.16^{\mathrm{a}}$ \\
\hline Potassium & $240.29 \pm 4.07^{\mathrm{a}}$ & $215.76 \pm 3.03^{b}$ & $232.51 \pm 2.17^{a}$ & $242.94 \pm 3.22^{\mathrm{a}}$ \\
\hline Magnesium & $11.60 \pm 0.93^{\mathrm{a}}$ & $11.52 \pm 1.09^{a}$ & $11.75 \pm 0.34^{\mathrm{a}}$ & $12.43 \pm 0.52^{\mathrm{a}}$ \\
\hline Calcium & $17.71 \pm 1.08^{\mathrm{a}}$ & $17.64 \pm 0.51^{\mathrm{a}}$ & $18.50 \pm 0.31^{\mathrm{a}}$ & $18.53 \pm 0.45^{\mathrm{a}}$ \\
\hline Iron & $0.62 \pm 0.04^{\mathrm{a}}$ & $0.49 \pm 0.03^{\mathrm{b}}$ & $0.54 \pm 0.02^{\mathrm{b}}$ & $0.66 \pm 0.02^{\mathrm{a}}$ \\
\hline Zinc & $0.07 \pm 0.002^{\mathrm{a}}$ & $0.05 \pm 0.003^{\mathrm{b}}$ & $0.06 \pm 0.002^{\mathrm{a}}$ & $0.07 \pm 0.005^{\mathrm{a}}$ \\
\hline Copper & $0.06 \pm 0.003^{\mathrm{a}}$ & $0.06 \pm 0.002^{\mathrm{a}}$ & $0.072 \pm 0.003^{b}$ & $0.07 \pm 0.002^{b}$ \\
\hline Phosphorus & $19.77 \pm 0.23^{\mathrm{a}}$ & $19.64 \pm 0.12^{\mathrm{a}}$ & $19.04 \pm 0.18^{\mathrm{b}}$ & $19.39 \pm 0.29^{\mathrm{ab}}$ \\
\hline Manganese & $0.076 \pm 0.005^{\mathrm{a}}$ & $0.06 \pm 0.002^{\mathrm{b}}$ & $0.06 \pm 0.003^{\mathrm{b}}$ & $0.07 \pm 0.003^{\mathrm{ab}}$ \\
\hline
\end{tabular}

\section{CONCLUSION}

In the current study, some physical and chemical quality parameters of the jujube fruit (Zizyphus jujuba Mill), which is cultivated in Turkey, at different maturation stages were investigated. The results are summarized below;

a) The physical properties and chemical composition of the jujube fruit changed depending on the maturation stage.

b) Increment in size and weight of jujube fruits was observed during maturation. c) Although the amount of water-soluble vitamins decreases with the maturation, fully mature jujube fruit is rich in water-soluble vitamins with the content of 789.05 $\mathrm{mg} \mathrm{kg}^{-1} \mathrm{DW}$ vitamin C, $0.2733 \mathrm{mg} \mathrm{kg}^{-1} \mathrm{DW}$ thiamine, $0.8033 \mathrm{mg} \mathrm{kg}^{-1} \mathrm{DW}$ pyridoxine, $0.4100 \mathrm{mg} \mathrm{kg}^{-1} \mathrm{DW}$ riboflavin and $8.8333 \mathrm{mg} \mathrm{kg}^{-1} \mathrm{DW}$ niacin.

d) The amount of organic acid in the jujube fruit changed with the maturation, and malic acid was found to be the major organic acid at all maturation stages. The highest organic acid content was obtained from the jujube fruits at YM stage.

e) In the jujube fruit, the major sugars were glucose and fructose at the GM stage, whereas the sucrose was the major sugar at the RM stage.

f) The jujube fruit is a very rich fruit in terms of phenolic compounds, and its phenolic compound composition changed with the maturation. While the major phenolic compound at the GM stage was catechin, in fully mature jujube fruits chlorogenic acid was the major phenolic compound.

g) Trans-resveratrol is an important antioxidant, and the content of transresveratrol found in jujube fruit was examined for the first time in this study. No trans-resveratrol was detected at RM stage. However, trans-resveratrol determined as $0.2166,0.1366$ and $0.07 \mathrm{mg} \mathrm{kg}^{-1} \mathrm{DW}$ at GM, YM and HRM stage, respectively h) Total phenolic content and antioxidant capacity of the jujube fruit decreased with the maturation.

i) Jujube fruit is rich in minerals, especially in terms of potassium.

j) Additionally, consumers generally prefer the last maturation stage of the fruits However, this study showed that jujube fruits at GM, YM and HM have significantly amound of bioactive compounds. It may be recommended that more benefit in terms of health can be obtained from the fruits at these stages by consuming or producing different products such as powder or drug with extracts of the jujube fruits for food supplement or tea obtained from dried pulps.
Consequently, the jujube fruits cultivated in Turkey can be regarded as high nutritional value fruit in terms of bioactive substances and mineral content However, limited studies are current on the physical and chemical properties of the jujube fruits cultivated in Turkey. Therefore, there is needed to further studies to determine nutritional value of the jujube fruits grown in Turkey.

Acknowledgments: This study was supported by Pamukkale University with grant number 2018FEBE024.

\section{REFERENCES}

Akbolat, D., Ertekin, C., Menges, H.O., Ekinci, K. \& Erdal, I. (2008) Physical and nutritional properties of jujube (Zizyphus jujuba Mill.) growing in Turkey. Asian Journal of Chemistry, 20(1), 757-766.

Bansal, V., Sharma, A., Ghanshyam, C. \& Singla, M. L. (2015) Rapid HPLC method for determination of vitamin c, phenolic acids, hydroxycinnamic acid, and flavonoids in seasonal samples of emblica officinalis juice. Journal of Liquid Chromatography \& Related Technologies, 38(5), 619-624. https://doi.org/10.1080/10826076.2014.936608

Bood, K. G. \& Zabetakis, I. (2002) The biosynthesis of strawberry flavor (II) Biosynthetic and molecular biology studies. Journal of Food Science, 67(1), 2-8 https://doi.org/10.1111/j.1365-2621.2002.tb11349.x

Brummell, D. A. (2006) Cell wall disassembly in ripening fruit. Functional Plant Biology, 33(2), 103-119.

Cemeroğlu, B.S., 2013. Gıda Analizleri, Ankara: Bizim Grup Publishing, Ankara, Turkey.

Choi, S.H., Ahn, J.B., Kim, H.J., Im, N.K., Kozukue, N., Levin, C.E. \& Friedman M. (2012) Changes in free amino acid, protein, and flavonoid content in jujube (Ziziphus jujube) fruit during eight stages of growth and antioxidative and cancer cell inhibitory effects by extracts. Journal of Agricultural and Food Chemistry, 60 10245-10255. https://doi.org/10.1021/jf302848u

Cosmulescu, S., Trandafir, I., Violeta, N. O. U. R., Achim, G., Mihai, B. O. T. U. \& Iordanescu, O. (2018) Variation of bioactive compounds and antioxidant activity of Jujube (Ziziphus jujuba) fruits at different stages of ripening. Notulae Botanicae 
Horti Agrobotanici Cluj-Napoca, 46(1), 134-137. https://doi.org/ 10.15835/nbha46110752

Dönmez A. (2015) Drying Kinetics of Resveratrol and Water-Soluble Vitamins of Some Grape Varieties Grown in Denizli Region, MSc. Thesis, Pamukkale University, Institute of Science, Denizli, Turkey.

Ekinci, R., \& Kadakal, C. (2005) Determination of seven water-soluble vitamins in tarhana, a traditional Turkish cereal food, by high-performance liquid chromatography. ACTA chromatographica, 15, 289.

Gao, Q. H., Wu, C. S., Wang, M., Xu, B. N. \& Du, L. J. (2012b). Effect of drying of jujubes (Ziziphus jujuba Mill.) on the contents of sugars, organic acids, $\alpha$ tocopherol, $\beta$-carotene, and phenolic compounds. Journal of Agricultural and Food Chemistry, 60(38), 9642-9648. https://doi.org/10.1021/jf3026524

Gao, Q. H., Wu, C. S., Yu, J. G., Wang, M., Ma, Y. J. \& Li, C. L. (2012a) Textural characteristic, antioxidant activity, sugar, organic acid, and phenolic profiles of 10 promising jujube (Ziziphus jujuba Mill.) selections. Journal of Food Science, 77(11), C1218-C1225. https://doi.org/10.1111/j.1750-3841.2012.02946.x Gao, Q.H., Wu, P.T., Liu, J.R., Wu, C.S., Parry, J.W. \& Wang, M. (2011) Physicochemical properties and antioxidant capacity of different jujube (Ziziphus jujuba Mill.) cultivars grown in loess plateau of China. Scientia Horticulturae, 130(1), 6772. https://doi.org/10.1016/j.scienta.2011.06.005

Giuffrè, A.M. (2013) High performance liquid chromatography-diode array detector (HPLC-DAD) detection of trans-resveratrol: evolution during ripening in grape berry skins. African Journal of Agricultural Research, 8, 224-229. https://doi.org/10.5897/AJAR11.2257

Gull, J., Sultana, B., Anwar, F., Naseer, R., Ashraf, M. \& Ashrafuzzaman, M. (2012) Variation in antioxidant attributes at three ripening stages of guava (Psidium guajava L.) fruit from different geographical regions of Pakistan. Molecules, 17(3), 3165-3180. https://doi.org/10.3390/molecules17033165 Guo, S., Duan, J.A., Tang, Y.P., Zhu, Z.H., Qian, Y.F., Yang, N.Y., Shang, E.X \& Qian, D.W. (2010) Characterization of nucleosides and nucleobases in fruits of Ziziphus jujuba by UPLC-DAD-MS. Journal of Agricultural and Food Chemistry, 58(19), 10774-10780. https://doi.org/10.1021/jf102648q

Hernandez, F., Noguera-Artiaga, L., Burlo, F., Wojdylo, A., Cabonell-Barrachina A.A. \& Legua, P. (2016) Physico-chemical, nutritional, and volatile composition and sensory profile of Spanish jujube (Ziziphus jujube Mill.) fruits. Journal of the Science of Food and Agriculture, 96(8), 2682-2691. https://doi.org/10.1002/jsfa.7386.

Hudec, J., Burdová, M., Kobida, L. U., Komora, L., Macho, V., Kogan, G., Turianica, I., Kochanova, R., Lozek, O., Haban, M. \& Chlebo, P. (2007) Antioxidant capacity changes and phenolic profile of Echinacea purpurea, nettle (Urtica dioica L.), and dandelion (Taraxacum officinale) after application of polyamine and phenolic biosynthesis regulators. Journal of Agricultural and Food Chemistry, 55(14), 5689-5696. https://doi.org/10.1021/jf070777c.

Karkacier, M., Erbas, M., Uslu, M. K., \& Aksu, M. (2003) Comparison of different extraction and detection methods for sugars using amino-bonded phase HPLC. Journal of Chromatographic Science, 41(6), 331-333.

Li, J.W., Fan, L.P., Ding, S.D. \& Ding, X.L. (2007) Nutritional composition of five cultivars of Chinese jujube. Food Chemistry, 10, 454-460. https://doi.org/10.1016/j.foodchem.2006.08.016

Liu, N., Yang, M., Huang, W., Wang, Y., Yang, M., Wang, Y., \& Zhao, Z. (2017) Composition, antioxidant activities and hepatoprotective effects of the water extract of Ziziphus jujuba cv. Jinsixiaozao. RSC Advances, 7(11), 6511-6522. https://doi.org/10.1039/C6RA27516H

Moradinezhad, F., Setayesh, F., Mahmoodi, S. \& Khayyat, M. (2016) Physicochemical properties and nutritional value of jujube (Ziziphus jujuba Mill.) fruit at different maturity and ripening stages. International Journal of Horticultural Science and Technology, 3(1), 43-50. https://doi.org/10.22059/IJHST.2016.58160 NMKL (Nordic Committee on Food Analysis), 186, http://www.nmkl.org/Engelsk/index.htm (2007).

Otağ, M. R., (2015) "Denizli Çal yöresinde yetișen bazı üzüm çeșitlerinin farklı olgunlaşma evreleri ve kurytulması sonrası bazı özellikleri ile resveratrol içeriğinin belirlenmesi", PhD thesis, Pamukkale University Institute of Science.

Pareek, S. (2013) Nutritional composition of jujube fruit. Emirates Journal of Food and Agriculture, 25, 463-470. https://doi.org/10.9755/ejfa.v25i6.15552

Patel, P. R. \& Rao, T. V. R. (2009) Physiological changes in relation to growth and ripening of khirni [Manilkara hexandra (Roxb.) Dubard] fruit. Fruits, 64(3), 139146. https://doi.org/10.1051/fruits/2009009

Prasanna, V., Prabha, T. N., \& Tharanathan, R. N. (2007) Fruit ripening phenomena-an overview. Critical Reviews in Food Science and Nutrition, 47(1), 1-19. https://doi.org/10.1080/10408390600976841

Singh, G., \& Pai, R. S. (2014) A rapid reversed-phase HPLC method for analysis of trans-resveratrol in PLGA nanoparticulate formulation. ISRN Chromatography. https://doi.org/10.1155/2014/248635

Singleton, V. L., \& Rossi, J. A. (1965) Colorimetry of total phenolics with phosphomolybdic-phosphotungstic acid reagents. American Journal of Enology and Viticulture, 16(3), 144-158.

Song, J., Bi, J., Chen, Q., Wu, X., Lyu, Y. \& Meng, X. (2019) Assessment of sugar content, fatty acids, free amino acids, and volatile profiles in jujube fruits at different ripening stages. Food Chemistry, 270, 344-352. https://doi.org/10.1016/j.foodchem.2018.07.102

Soyer, Y., Koca, N. \& Karadeniz, F. (2003) Organic Acid Profile of Turkish White Grapes and Grape Juices. Journal of Food Composition and Analysis, 16, 629-636. https://doi.org/10.1016/S0889-1575(03)00065-6

Tepe, F.B., Tepe, T.K., \& Ekinci, A. (2021) Impact of air temperature on drying characteristics and some bioactive properties of kiwi fruit slices. Chemical Industry and Chemical Engineering Quarterly, (00), 26-26. https://doi.org/10.2298/CICEQ210126026T

Thaipong, K., Boonprakob, U., Crosby, K., Cisneros-Zevallos, L. \& Byrne, D. H. (2006) Comparison of ABTS, DPPH, FRAP, and ORAC assays for estimating antioxidant activity from guava fruit extracts. Journal of Food Composition and Analysis, 19(6-7), 669-675. https://doi.org/10.1016/j.jfca.2006.01.003

Toor, R. K. \& Savage, G. P. (2005) Antioxidant activity in different fractions of tomatoes. Food Research International, 38(5), 487-494. https://doi.org/10.1016/j.foodres.2004.10.016

Wang, B., Huang, Q., Venkitasamy, C., Chai, H., Gao, H., Cheng, N., Cao, W., Lv, X. \& Pan, Z. (2016) Changes in phenolic compounds and their antioxidant capacities in jujube (Ziziphus jujuba Miller) during three edible maturity stages. LWT-Food Science and Technology, 66, 56-62. https://doi.org/10.1016/j.1wt.2015.10.005

Wang, C., Cheng, D., Cao, J. \& Jiang, W. (2013) Antioxidant capacity and chemical constituents of chinese jujube (Ziziphus jujuba mill.) at different ripening stages. Food Science and Biotechnology, 22(3), 639-644. https://doi.org/10.1007/s10068-013-0125-6

Wang, Y.G., Ma, Y.L., Liu, X.F., Wang, X.L., Wang, Y.L. \& Ren, H.W. (2014) Composition analysis and nutritional evaluation of Zizyphus jujube Mill. $\mathrm{Cv}$. Xiaokou. Modern Food Science and Technology, 30, 23. https://doi.org/10.13982/j.mfst.1673-9078.2014.10.040

Wojdylo, A., Carbonell-Barrachina, A.A., Legua, P. \& Hernandez, F. (2016b) Phenolic composition, ascorbic acid content, and antioxidant capacity of Spanish jujube (Ziziphus jujube Mill.) fruits. Food Chemistry, 201, 307-314 https://doi.org/10.1016/j.foodchem.2016.01.090

Wojdyło, A., Figiel, A., Legua, P., Lech, K., Carbonell-Barrachina, Á. A., \& Hernández, F. (2016a) Chemical composition, antioxidant capacity, and sensory quality of dried jujube fruits as affected by cultivar and drying method. Food Chemistry, 207, 170-179. https://doi.org/10.1016/j.foodchem.2016.03.099

Wu, C. S., Gao, Q. H., Guo, X. D., Yu, J. G., \& Wang, M. (2012) Effect of ripening stage on physicochemical properties and antioxidant profiles of a promising table fruit 'pear-jujube'(Zizyphus jujuba Mill.). Scientia Horticulturae, 148, 177-184. https://doi.org/10.1016/j.scienta.2012.09.026

Xie, P. J., You, F., Huang, L. X. \& Zhang, C. H. (2017) Comprehensive assessment of phenolic compounds and antioxidant performance in the developmental process of jujube (Ziziphus jujuba Mill.). Journal of Functional Foods, 36, 233-242. https://doi.org/10.1016/j.jff.2017.07.012

Xue, Z., Feng, W., Cao, J., Cao, D. \& Jiang, W. (2009) Antioxidant activity and total phenolic contents in peel and pulp of Chinese jujube (Ziziphus jujuba Mill) fruits. Journal of Food Biochemistry, 33(5), 613-629. https://doi.org/10.1111/j.1745-4514.2009.00241.x

Yaşa F. (2016) Türkiye'de yetiștirilen hünnap meyvesinin bileșimi ve meyvenin kurutulması sırasında bileşiminde meydana gelen değişimler (Master's thesis, Pamukkale University Institute of Science).

Zhang, H., Jiang, L., Ye, S., Ye, Y. \& Ren, F. (2010) Systematic evaluation of antioxidant capacities of the ethanolic extract of different tissues of jujube (Ziziphus jujuba Mill.) from China. Food and Chemical Toxicology, 48(6), 14611465. https://doi.org/10.1016/j.fct.2010.03.011

Zhao, H. X., Zhang, H. S., \& Yang, S. F. (2014) Phenolic compounds and its antioxidant activities in ethanolic extracts from seven cultivars of Chinese jujube. Food Science and Human Wellness, 3(3-4), 183-190 https://doi.org/10.1016/j.fshw.2014.12.005

Zheng, H. Z., Kim, Y. I. \& Chung, S. K. (2012) A profile of physicochemical and antioxidant changes during fruit growth for the utilisation of unripe apples. Food Chemistry, 131(1), 106-110. https://doi.org/10.1016/j.foodchem.2011.08.038 Zozio, S., Servent, A., Cazal, G., Mbéguié-A-Mbéguié, D., Ravion, S., Pallet, D., \& Abel, H. (2014) Changes in antioxidant activity during the ripening of jujube (Ziziphus mauritiana Lamk). Food Chemistry, 150, 448-456. https://doi.org/10.1016/j.foodchem.2013.11.022 